\title{
New data on the development of the brachiopod Hemithiris psittacea (Rhynchonelliformea: Rhynchonellida)
}

\begin{abstract}
T.V. Kuzmina
Lomonosov Moscow State University, Vorobjevi gory 1-12, Moscow, Russian Federation, 119991. E-mail: kuzmina-t@yandex.ru

ABSTRACT: Brachiopods are marine invertebrates with a pelago-benthic life cycle. The life cycle and structure of planktonic stages vary among brachiopod taxa. Many rhynchonelliform brachiopods, including those in the order Rhynchonellida, brood three-lobed larvae (i.e., the cephalulae) in the mantle cavity. However, no cephalulae were found in the mantle cavity of the rhynchonellid Hemithiris psittacea (Gmelin, 1791) from the White Sea. In this research, artificial insemination and induced spawning were used to study the ontogeny of H. psittacea from the White Sea Biological Station of Moscow State University (Kandalakshskii Bay of the White Sea). After fertilization, a thick egg envelope forms around the zygote and adheres to the substrate. Cleavage, gastrulation, and formation of the threelobed cephalula occur within the egg envelope. A worm-like competent cephalula hatches from the egg envelope and swims along the substrate rather than in the water column. The cephalula of $H$. psittacea differs in structure from the terebratulid larva, which actively swims in the water column. In contrast to terebratulid larva, the cephalula of H. psittacea lacks the eyespots and has shorter and less abundant setae. Development of $H$. psittacea from the White Sea proceeds in the external environment rather in the lophophore of the female. These results are inconsistent with the published data on $H$. psittacea from the San Juan Channel (Washington, USA), whose larvae develop outside the egg envelope in the lophophore of the female. A possible explanation is that Hemithiris from the San Juan Channel and from the White Sea represent separate species. The current report for $H$. psittacea from the White Sea is the first to describe embryonization of larval development for a rhynchonelliform.

How to cite this article: Kuzmina T.V. 2021. New data on the development of the brachiopod Hemithiris psittacea (Rhynchonelliformea: Rhynchonellida) // Invert. Zool. Vol.18. No.3. P.321-331. doi: 10.15298/invertzool.18.3.06
\end{abstract}

KEY WORDS: Brachiopoda, larval development, cephalula, Hemithiris psittacea, embryonization.

\section{Новые данные по развитию брахиоподы Hemithiris psittacea (Rhynchonelliformea: Rhynchonellida)}

\section{Т.В. Кузьмина}

Кафедра зоологии беспозвоночных, Биологический факультет МГУ имени М.В. Ломоносова, Ленинские горы 1-12, 119991 Москва, Россия.E-mail: kuzmina-t@yandex.ru

The paper is devoted to 70th anniversary of Prof. V.V. Malakhov.

Статья посвящена 70-летию со дня рождения проф., акад. В.В. Малахова. 
РЕЗЮМЕ: Брахиоподы - морские беспозвоночные животные с пелаго-бентическим жизненным циклом. Жизненные циклы и строение планктонных стадий различаются в разных группах брахиопод. Для многих ринхонеллиформных брахиопод, в том числе и представителей отряда Rhynchonellida, характерно вынашивание трехлопастных личинок, цефалул, в мантийной полости. Однако до сих не были обнаружены цефалулы в мантийной полости ринхонеллиды Hemithiris psittacea (Gmelin, 1791), обитающей в Белом море. В данной работе изучено развитие брахиоподы $H$. psittacea, собранной в окрестностях Беломорской биологической станции МГУ (Кандалакшский залив Белого моря), методом искусственного оплодотворения и индукции нереста. Было показано, что после оплодотворения вокруг зиготы формируются толстая яйцевая оболочка, которая прилипает ко дну. Под яйцевой оболочкой происходит дробление, гаструляция и формирование трехлопастной цефалулы. Из яйцевых оболочек выходит червеобразная компетентная цефалула и плавает вдоль поверхности дна. Строение цефалул $H$. psittacea отличается от личинок теребратулид, которые активно плавают в толще воды. Цефалулы $H$. psittacea лишены глазных пятен, имеют укороченные малочисленные щетинки. Было показано, что развитие данного вида происходит во внешней среде. Полученные результаты противоречат данным относительно этого же вида брахиопод, собранного в канале Сан Хуан (Вашингтон, США), для которого описано личиночное развитие вне яйцевых оболочек в лофофоре материнской особи. Было предположено, что Hemithiris из канала Сан Хуан и Белого моря представляют собой разные виды. В данной работе впервые для ринхонеллиформных брахиопод был описан жизненный цикл с эмбрионизацией личиночного развития.

Как цитировать эту статью: Kuzmina T.V. 2021. New data on the development of the brachiopod Hemithiris psittacea (Rhynchonelliformea: Rhynchonellida) // Invert. Zool. Vol.18. No.3. P.321-331. doi: 10.15298/invertzool.18.3.06

КЛЮЧЕВЫЕ СЛОВА: брахиоподы, личиночное развитие, цефалула, Hemithiris psittacea, эмбрионизация.

\section{Introduction}

Brachiopods are marine invertebrates with a pelago-benthic life cycle. The adults are protected by a bivalved shell, which in most cases is attached to the substrate by a pedicle. The adults use their tentacle apparatus, the lophophore, for feeding and respiration. Dispersal is performed by planktonic larvae or juveniles (Lüter, 2001a; Kuzmina et al., 2019). Aspects of the life cycle and morphology of planktonic stages vary among brachiopod taxa. Four types of the planktonic stages have been recently distinguished: chaetotrocha, cephalula, chaetolopha, and tegulolopha (Malakhov et al., 2021). This terminological concept has been used in the present paper.
The phylum Brachiopoda is divided into three subphyla: Linguliformea, Craniiformea, and Rhynchonelliformea(Williams et al., 1996). The craniiforms have a calcareous shell without articulation (Williams et al., 2000a). In the life cycle of recent craniiforms, fertilization occurs in the water column, the ciliary blastula hatches from the egg envelope, and then the lecithotrophic larva, the chaetotrocha, forms (Nielsen, 1991). The chaetotrocha is divided into a rounded apical lobe with a ciliary band and a body lobe with three pairs of bundles of larval setae (Nielsen, 1991; Altenburger, Wanninger, 2010; Altenburger et al., 2013). The planktonic development requires about 4 days (Nielsen, 1991). The craniiform life cycle possibly resembles the life cycle of the brachiopod ancestor (Kuzmina et al., 2019). 
The linguliforms have an organophosphatic inarticulate shell (Williams et al., 2000b). Recent linguliforms are represented only by the order Lingulida with two superfamilies: Linguloidea and Discinoidea. The two superfamilies differ substantially in biology: the lingulids live in burrows, while the discinids use a short muscular pedicle to attach to hard substrates (Emig, 1997). The recent discinids have three planktonic stages in their life cycle. The first stage, the two-lobed lecithotrophic larva (the cephalula), hatches from its egg envelope and has a ciliary band on the apical lobe and three pairs of long larval setae on the body lobe (Chuang, 1977; Freeman, 1999; Lüter, 2001a). In the water column, the cephalula transforms into the second stage, the chaetolopha, which is planktotrophic and has a rudimentary lophophore (Chuang, 1977; Freeman, 1999). With the secretion of a shell, the chaetolopha transforms into the third developmental stage, the tegulolopha. In lingulids, the planktotrophic stage, the tegulolopha, with a shell and a lophophore hatches from the egg envelope, and grows and swims in the water column (Yatsu, 1902). The linguliform tegulolopha swims for a several weeks and then settles on the bottom (Yatsu, 1902; Williams, Carlson, 2007). Researchers have suggested that the lingulid life cycle is characterized by the embryonization of all developmental stages except for the tegulolopha and is the most derived life cycle among all recent brachiopods (Kuzmina et al., 2019; Malakhov et al., 2021).

The rhynchonelliforms have a calcareous shell, the posterior region of which has welldeveloped complementary articulatory structures (Williams et al., 2000c). This subphylum is the most widespread and diverse group among brachiopods and contains three extant orders: Rhynchonellida, Thecideida, and Terebratulida. The life cycle of the recent rhynchonelliforms possibly evolved from the craniiformlike life cycle (Kuzmina et al., 2019) and includes the lecithotrophic larval stage, the cephalula. The rhynchonelliform cephalula consists of three lobes: an apical lobe with a ciliary band, a mantle lobe with two pairs of setal bundles, and a pedicle lobe (Kovalevsky, 1874, 1883; Conklin, 1902; Percival, 1944, 1960; Malakhov, 1976, 1983; Kuzmina et al., 2019). Most rhynchonelliforms are gonochoristic and exhibit external fertilization in the water column. The ciliary blastula or early gastrula hatches from the egg envelope (Chuang, 1996; Pennington et al., 1999; Lüter, 2000; D'Hondt, Franzen, 2001; Kuzmina et al., 2019). In the water column, the gastrula gradually transforms into the three-lobed cephalula, which swims in the water column for 3 or 4 days before it settles and attaches to the substrate by its pedicle lobe. The mantle lobe then reverses and envelops the apical lobe (Percival, 1960; Stricker, Reed, 1985; Chuang, 1996; Pennington et al., 1999).

In some rhynchonelliforms, however, this life cycle is transformed in that fertilization occurs and larvae are brooded in the mantle cavity (Kovalevsky, 1874; Shipley, 1883; Hoverd, 1985; Lüter, 2001b; Seidel et al., 2012; Kaulfuss et al., 2013). For instance, the brooding of larvae on the brachial fold of the lophophore has been documented for Notosaria nigricans (Sowerby, 1846) (Rhynchonellida), which has a spirolophous lophophore (Hoverd, 1985). Long (1964) reported that another rhynchonellid, Hemithiris psittacea (Gmelin, 1791) (collected from the San Juan Channel, Washington, USA), also broods its larvae in the lophophore. However, although the larvae of $H$. psittacea from the White Sea Biological Station of Moscow State University have been frequently examined by researchers and students, the larvae have never been observed in the lophophore or in the plankton (unpublished observations). The life cycle of $H$. psittacea therefore requires detailed examination.

The current report describes the development of larvae of the rhynchonellid brachiopod H. psittacea from the White Sea. Data on the ontogeny of recent rhynchonelliforms are also analyzed. Finally, possible explanation for the differences in the development of $H$. psittacea collected in the San Juan Channel and the White Sea is considered. 


\section{Materials and methods}

H. psittacea is a gonochoristic species without sexual dimorphism. Sixty adults of $H$. psittacea were collected at a depth of $9 \mathrm{~m}$ in August 2020 at the White Sea Biological Station of Moscow State University (Kandalakshskii Bay of the White Sea). The specimens were kept in sea water in the laboratory conditions at $2-4{ }^{\circ} \mathrm{C}$. Development was studied by two methods: artificial insemination and spawning induction.

The male and female gonads of $H$. psittacea are located in the coelomic canals of the mantle. For the artificial insemination, the valves were opened, and using a Pasteur pipette oocytes and sperm were obtained from the ovary and testis, respectively. The oocytes were washed with two changes of filtered sea water and were kept at $2-4{ }^{\circ} \mathrm{C}$ for $6 \mathrm{~h}$ to enable the shedding of the follicle cells and the breakdown of germinal vesicles in the eggs. The sperm was kept for 15 min at $4{ }^{\circ} \mathrm{C}$. Sperm motility was monitored by light microscopy. Five milliliters of a sperm suspension was added to $300 \mathrm{ml}$ of filtered sea water with the eggs. In $1 \mathrm{~h}$, the zygotes were washed three times with filtered sea water. The embryos were kept in $300 \mathrm{ml}$ glass vessels at a concentration of 1 larva per $3 \mathrm{~mm}^{3}$ of water (2$4{ }^{\circ} \mathrm{C}$ ). The water was changed once each day. When the competent larvae formed, stones were placed in the vessels for the larval settlement.

Spawning was induced by adding sperm, obtained as described in the previous paragraph, to the $300 \mathrm{ml}$ vessel containing 4 females at $2{ }^{\circ} \mathrm{C}$. After $5 \mathrm{~h}$, the vessel with females was washed three times with filtered sea water.

The eggs, embryos, and larvae were studied and photographed with a Zeiss Axioplan 2 light microscope equipped with Axioplan2 digital camera. The larvae and settled juveniles were studied and photographed with a Leica M165C stereo microscope equipped with a Leica DFC420 digital camera.

For scanning electron microscopy (SEM), the larvae were fixed in $2.5 \%$ phosphate-buffered glutaraldehyde. After the samples were further treated using standard SEM techniques, they were examined and photographed with a Vega3 Tescan scanning electron microscope.

\section{Results}

Spawning was induced by adding sperm to a vessel containing females. While spawning, the female slightly opens its valves and discharges unfertilized oocytes from the middle of the shell with the exhalant flow onto the surrounding substrate (Fig. 1A-B). The released oocytes are $160 \mu \mathrm{m}$ in diameter and lack the follicular cells and the germinal vesicle, i.e., they are ready for fertilization.
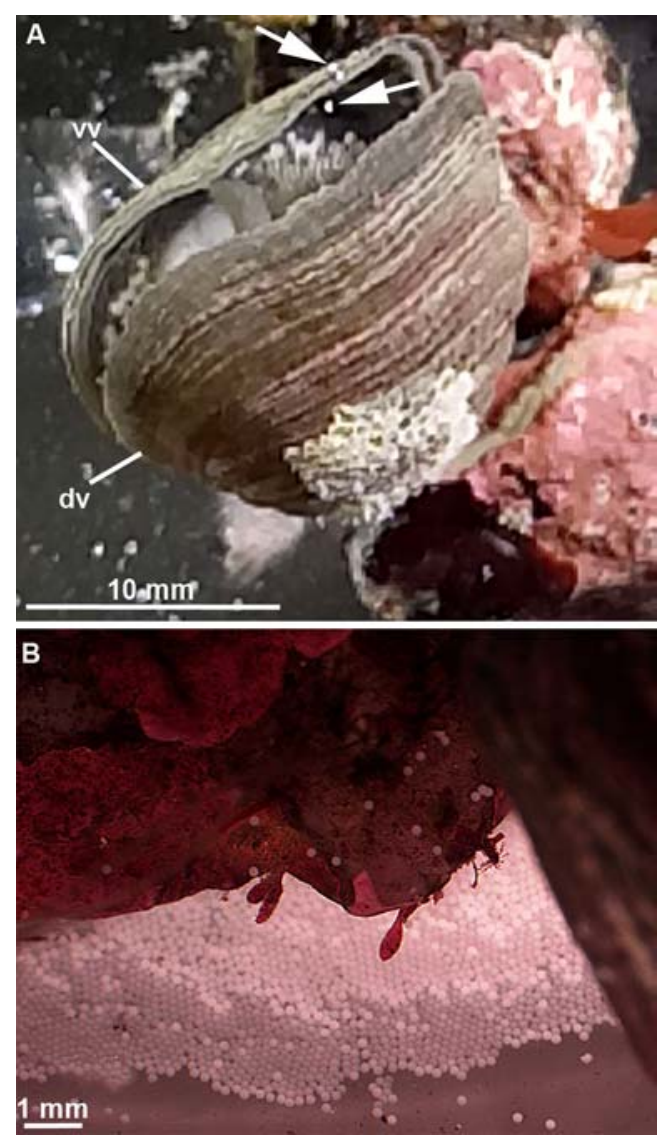

Fig. 1. The spawning of Hemithiris psittacea (light microscopy). A - spawning of oocytes; B - the released oocytes on the substrate.

Abbreviations: $\mathrm{dv}$ - dorsal valve; vv - ventral valve; arrows indicate released oocytes.

Рис. 1. Нерест Hemithiris psittacea (световая микроскопия). А - выброс ооцитов; В - выделенные ооциты на субстрате.

Обозначения: dv - дорсальная створка; vv - вентральная створка раковины; стрелки указывают на выходящие ооциты. 

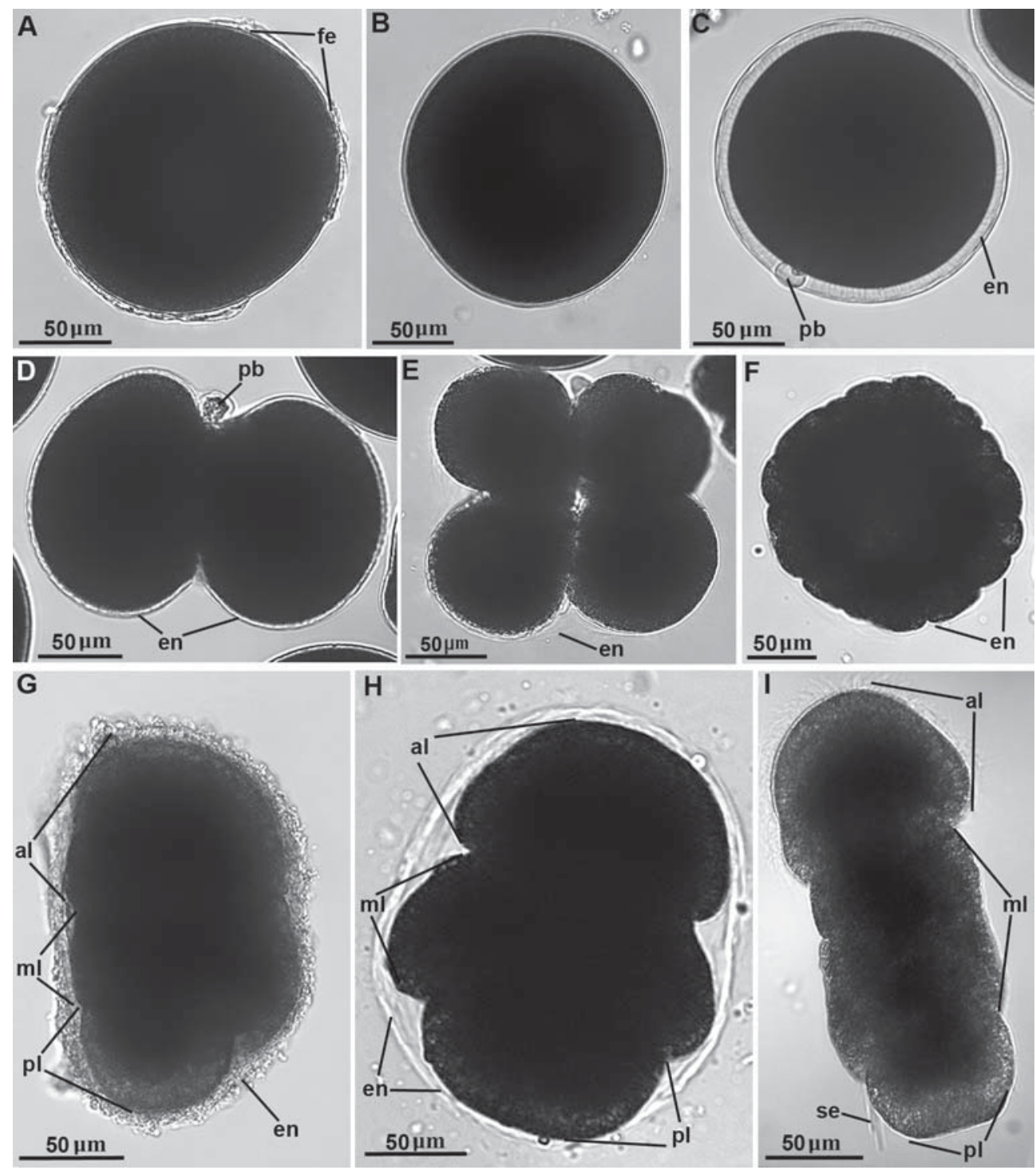

Fig. 2. Development of Hemithiris psittacea (light microscopy). A - the oocyte extracted from ovaries; B the oocyte that breaks down follicular cells; $\mathrm{C}$ - the zygote covered by the egg envelope; D - two-cell embryo; E - four-cell embryo; F - blastula; G - early three-lobed cephalula in the egg envelope, lateral view; $\mathrm{H}$ - early three-lobed cephalula in the egg envelope, dorsal view; I - competent three-lobed cephalula.

Abbreviations: al — apical lobe; en — egg envelope; fe — follicular envelope; $\mathrm{ml}$ - mantle lobe; $\mathrm{pb}$ - polar body; $\mathrm{pl}$ pedicle lobe; se - setae.

Рис. 2. Развитие Hemithiris psittacea (световая микроскопия). А - ооцит, выделенный из яичника; В ооцит, сбросивший фолликулярную оболочку; С - зигота, покрытая оболочкой; D - стадия двух бластомеров; Е - стадия четырех бластомеров; F — бластула; $\mathrm{G}$ - ранняя трехлопастная цефалула в яйцевой оболочке, вид сбоку; Н - ранняя трехлопастная цефалула в яйцевой оболочке, вид с дорсальной стороны; I - компетентная трехлопастная цефалула.

Обозначения: al - передняя лопасть; en - яйцевая оболочка; fe — фолликулярная оболочка; $\mathrm{ml}$ - мантийная лопасть; $\mathrm{pb}$ - редукционное тельце; $\mathrm{pl}$ — ножная лопасть; $\mathrm{se}$ - щетинки. 
All developmental stages were studied using the artificial insemination. The oocytes extracted from ovaries are enveloped by follicular cells and contain readily observed germinal vesicles (Fig. 2A). The mature oocytes are about $160 \mu \mathrm{m}$ in diameter. Before fertilization, the oocytes shed the follicular cells, and the germinal vesicle breaks down (Fig. 2B). At 10 minutes after fertilization, the zygotes become covered with an envelope that is up to $20 \mu \mathrm{m}$ thick, and a pair of polar bodies then forms (Fig. 2C). Further development occurred under the egg envelope, which adhered to the bottom of the glass vessel. Cleavage is total and equal (Fig. 2D-F). The first and the second cleavages are meridional and perpendicular to each other (Fig. 2D-E). A blastula about $180 \mu \mathrm{m}$ in diameter forms about 21 hours after fertilization (Fig. $2 \mathrm{~F})$. Within the egg envelope, gastrulation occurs, the blastopore closes, and the two-lobed stage composed of the apical and body lobes forms. At about 170 hours after fertilization, a three-lobed larva that is about $200 \mu \mathrm{m}$ long and is composed of the apical, mantle, and the pedicle lobes forms within the egg envelope. The setae at this stage are absent (Fig. 2G-H). The larva begins to move and rotate inside the egg envelope using the cilia covering the apical lobe. At about 300 hours after fertilization, a three-lobed competent larva, the cephalula, hatches from the egg envelope (Fig. 2I).

The cephalula is wormlike and about 250 $\mu \mathrm{m}$ long (Figs 2I, 3). The apical lobe is about 85 $\mu \mathrm{m}$ long and is completely covered with cilia; a ciliary band runs along the margin of the apical lobe (Figs 2I, 3A-C). Irregularly shaped cells are located under the apical lobe (Fig. 3C-D). The apical lobe lacks eyespots. The mantle lobe is elongated, with ring-shaped transverse constrictions (Fig. 2I). The ventral side of the mantle lobe is considerably longer than the dorsal side (Fig. 3C). The ventral side of the mantle lobe is about $105 \mu \mathrm{m}$ long, and the dorsal side of the mantle lobe is about $70 \mu \mathrm{m}$ long. The surface of the mantle lobe is sparsely covered with cilia; the ciliary band runs along the midline of the ventral side but does not reach the margin of the mantle lobe (Fig. 3A, C). Two pairs of spinose setal bundles form at this stage. One pair is located on the dorsal side of the mantle, and the other pair is located on the lateral sides of the mantle. The setae are few in number (from 1 to 3 setae in a bundle) and are very short, i.e., $<35$ $\mu \mathrm{m}$ long (Fig. 3E). The pedicle lobe is about 60 $\mu \mathrm{m}$ long and has a constriction on the dorsal side (Fig. 3C). The surface of the pedicle lobe is sparsely covered with cilia.

The competent cephalula of $H$. psittacea does not rise into the water column and swims only near the bottom (Fig. 4A). At about 19 days after fertilization, metamorphosing stages were evident. The larva selects a location on the substrate to which it attaches with its pedicle lobe; the mantle then gradually reverses and envelopes the apical lobe (Fig. 4B). At about 22 days after fertilization, the mouth opens in the middle of the apical lobe, and at about 26 days after fertilization, the rudiment of the brachial fold forms above the mouth, and the rudiments of the first pair of tentacles form on either side of the mouth (Fig. 4C). The shell is secreted on the external mantle surface (Fig. 4C-D). The larval setae are shed at this stage.

\section{Discussion}

In the current study, H. psittacea collected at $9 \mathrm{~m}$ depth developed in the laboratory at 2$4{ }^{\circ} \mathrm{C}$; this temperature corresponds to that of the shallow water layer (0-10 m depth) in Kandalakshskii Bay of the White Sea in June and in October-November (Prudkovsky et al., 2019). The development of $H$. psittacea from the San Juan Channel was studied by the method of artificial insemination by Freeman (2003) at $10-12{ }^{\circ} \mathrm{C}$ and by Long (1964) at $10^{\circ} \mathrm{C} ; \mathrm{H}$. psittacea in the San Juan Channel breeds in December and January (Long, 1964). The development of $H$. psittacea from fertilization to metamorphosis required 19 days according to our data, 12 days according to Freeman (2003), and 8 days according to Long (1964). The differences in the duration of the initial ontogenetic stages is probably the result of temperature, and development presumably takes longer in the White Sea than in the San Juan Channel because the water is colder in the White Sea. 

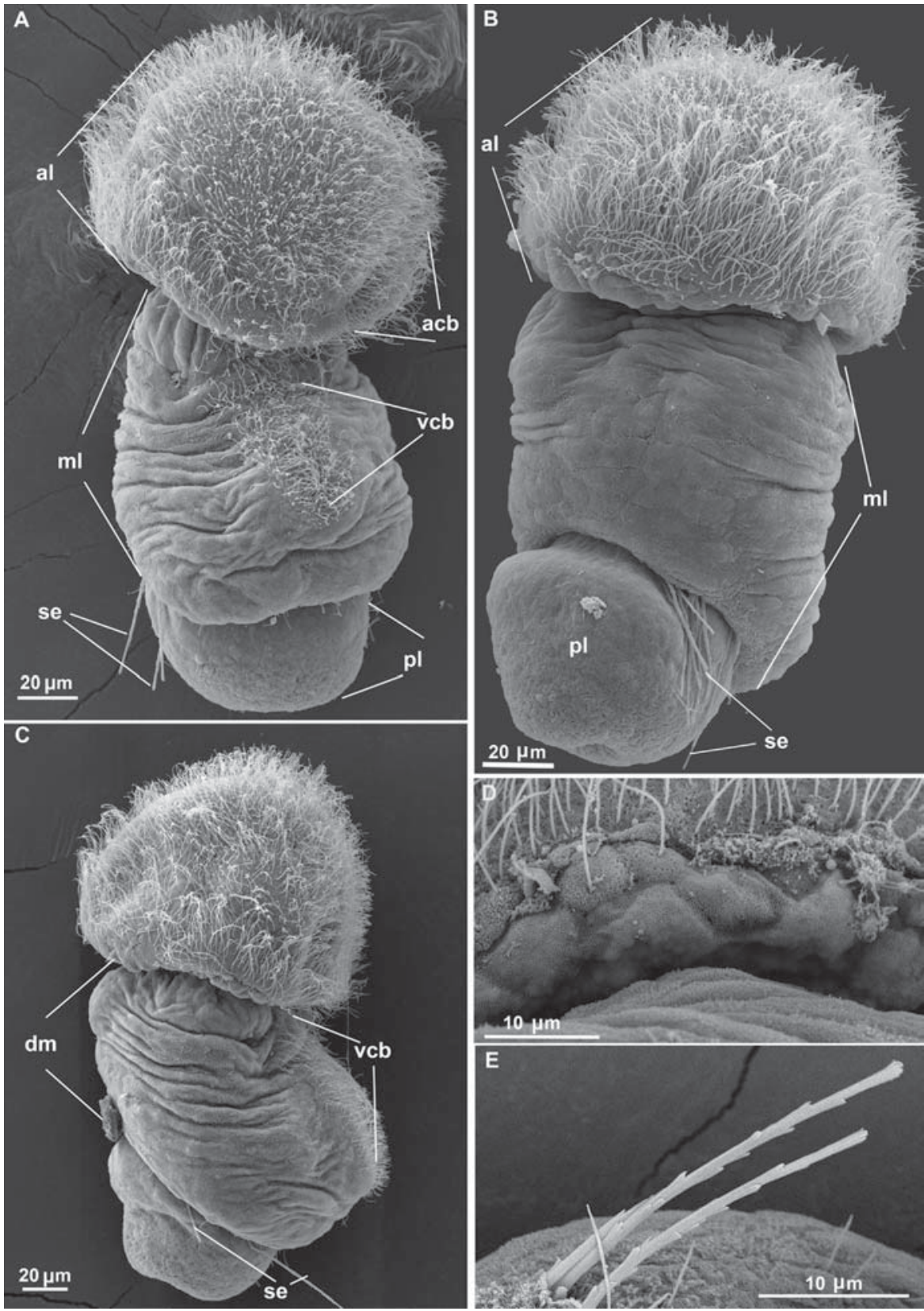

Fig. 3. Competent cephalula of Hemithiris psittacea (SEM). A — ventral view; B — dorsal view; C - lateral view; D - the irregularly shaped cells of the lower surface of the apical lobe; E - spinose setae.

Abbreviations: acb — ciliary band of apical lobe; al — apical lobe; $\mathrm{dm}$ — dorsal part of mantle lobe; $\mathrm{ml}$ — mantle lobe; $\mathrm{pl}$ - pedicle lobe; se - setae; vcb - ventral ciliary band.

Рис. 3. Компетентная цефалула Hemithiris psittacea (СЭМ). А - вид с вентральной стороны; В — вид с дорсальной стороны; C - вид сбоку; D - клетки неправильной формы на нижней поверхности апикальной лопасти; Е - игольчатые щетинки.

Обозначения: acb - pесничный шнур на апикальной лопасти; $\mathrm{al}$ — апикальная лопасть; $\mathrm{dm}$ — дорсальная часть мантийной лопасти; $\mathrm{ml}$ - мантийная лопасть; $\mathrm{pl}$ - ножная лопасть; se - щетинки; vcb - вентральный ресничный шнур. 


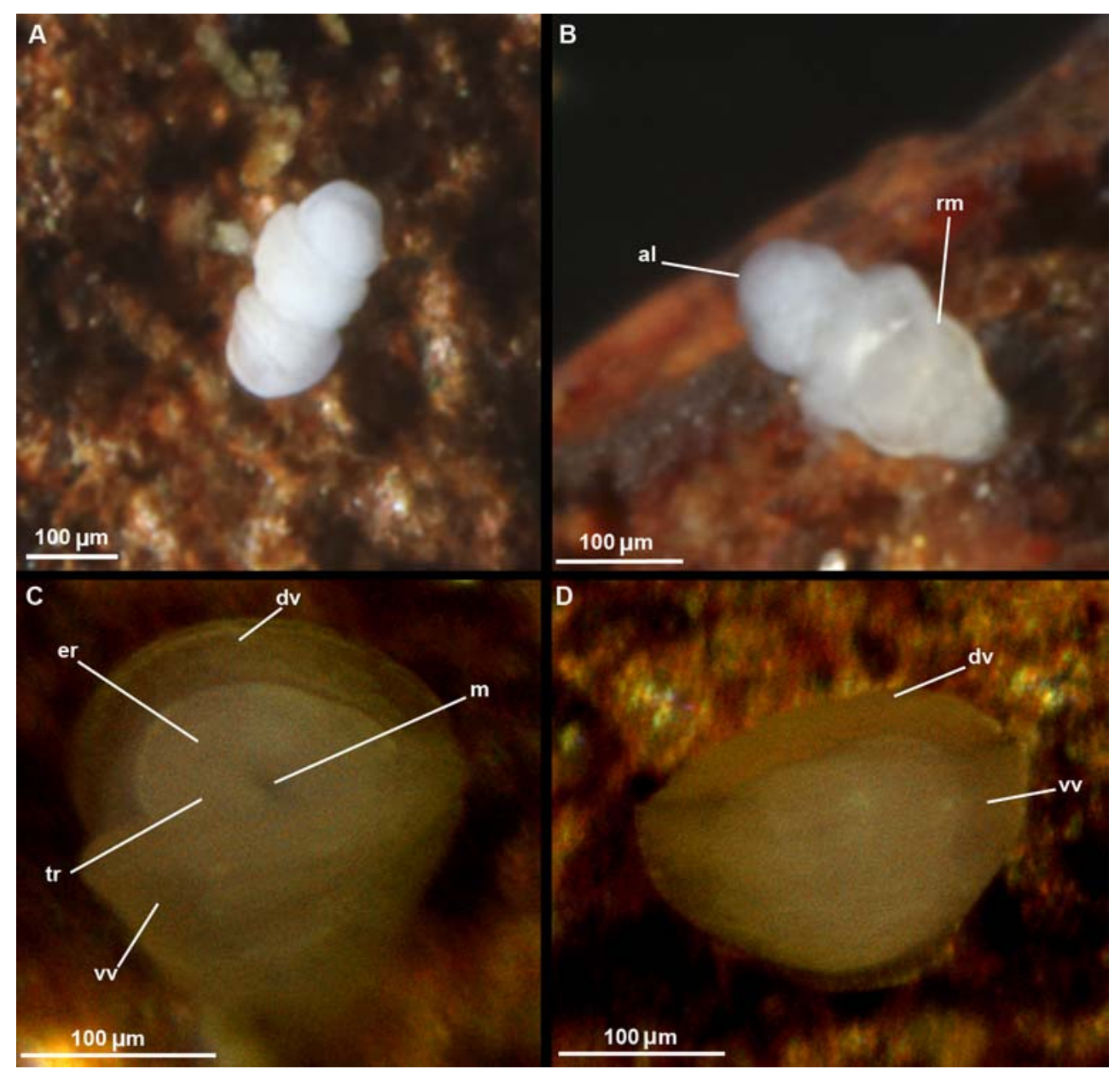

Fig. 4. Settlement and metamorphosis of Hemithiris psittacea (light microscopy). A - competent cephalula chooses a place on the substrate for settlement (photo by A. Prudkovsky); B - the mantle of the cephalula reverses after settlement(photo by A. Prudkovsky); C — juvenile with opened valves, D — juvenile with closed valves.

Abbreviations: al — apical lobe; $\mathrm{dv}$ - dorsal valve; er — rudiment of brachial fold; $\mathrm{m}$ - mouth; rv — reversed mantle; tr — tentacle rudiment; vv - ventral valve.

Рис. 4. Оседание и метаморфоз Hemithiris psittacea (световая микроскопия). А - компетентная личинка выбирает место для оседания (фото А. Прудковского); В — мантия выворачивается после оседания (фото А. Прудковского); C — ювениль с приоткрытыми створками; D — ювениль с закрытыми створками раковины.

Обозначения: al - апикальная лопасть; dv - дорсальная створка; er - зачаток брахиальной складки; $\mathrm{m}$ - рот; rv - вывернутая мантия; tr — зачаток щупальца; vv — вентральная створка раковины.

As described here, the general structure of the competent larvae, cephalulae, of the rhynchonellid $H$. psittacea resembles that of other rhynchonelliforms, e.g., the terebratulid Coptothyris grayi (Hirai, Fukushi, 1960; Kuzmina et al., 2019). The larva is composed of the apical, mantle, and pedicle lobes. Like the ceph- alula of $H$. psittacea from the San Juan Channel (Long, 1964), the cephalula of $H$. psittacea from the White Sea has an elongate, wormlike body. In rhynchonelliforms, the cephalula cilia are located on the apical lobe and form a ciliary band, which is better developed in C. grayi than in the H. psittacea from the White Sea. The 
mantle of the rhynchonelliform cephalula bears two pairs of setal bundles; the setae of $H$. psittace $a$ are less abundant and shorter than those of C. grayi, which has two pairs of massive setal bundles that are 2.5 times longer than the pedicle lobe (Hirai, Fukushi, 1960; Kuzmina et al., 2019). The differences in the cephalula structure of $H$. psittacea and C. grayi is probably related to their mode of life. The cephalulae of C. grayi and of most of other terebratulids actively swim in the water column and use their long setae for buoyancy and protection (Williams et al., 1997). In contrast, the cephalulae of the studied $H$. psittacea lives exclusively near the bottom and are worm-like; their short setae are not used for swimming and may have only sensory and protective functions. The presence of eyespots on the apical lobe is the characteristic feature of the most rhynchonelliform cephalulae (Williams et al., 1997; Lüter, 2007) and may be an ancestral character of rhynchonelliforms. All recent rhynchonellid cephalulae lack the eyespots (Williams et al., 1997). This may be explained by the brooding in the mantle cavity in some rhynchonellid species (Percival, 1960; Hoverd, 1985; Lüter, 2001b), or by external development in the egg envelope, as in $H$. psittacea from the White Sea, because in both cases the larvae do not need light for the orientation in the water column.

In H. psittacea, irregularly shaped cells are located on the apical lobe. Their size and form differ from the undulating row of large cells on the apical lobe of other rhynchonellid larvae (Lüter, 2001b). However, they possibly have the same function as the vesicular bodies on the apical lobe of terebratulids (Long, 1964; Stricker, Reed, 1985; Kuzmina et al., 2019).

The spawning induction assay revealed that H. psittacea from the White sea does not develop in the parental lophophore, as was previously recorded for $H$. psittacea in the San Juan Channel (Long, 1964), but on the substrate surrounding the female. The current study also revealed that $H$. psittacea development occurs within the thick egg envelope until the stage of the competent larva. These results contradict the previously published finding that the cephalula of $H$. psittacea hatches from the egg envelope at the blastula stage (Long, 1964; Freeman, 2003), as is known for the other rhynchonelliforms (Pennington et al., 1999; D'Hondt, Franzen, 2001; Kuzmina et al., 2019). It follows that the current report is the first to describe the embryonization of larval development in Rhynchonellida (Rhynchonelliformea). Such embryonization of larval development is also typical for recent linguliforms; in this development, a ciliary cephalula (Discinidae) or tegulolopha (Lingulidae) hatches from the egg envelope (Yatsu, 1902; Freeman, 1999; Lüter, 2001a). In craniiforms and most rhynchonelliforms, in contrast, the ciliary blastula or early gastrula hatches from the egg envelope (Chuang, 1996; Pennington et al., 1999; Nielsen, 1991; Williams et al., 1997; D'Hondt, Franzen, 2001; Kuzmina et al., 2019). Embryonization of larval development probably arose independently in different brachiopod subphyla. In Linguliformea, the planktonic stage of the life cycle is prolonged due to the lifting of juveniles into the water column, where they begin to swim, feed, and disperse, while their larval development was retained to the egg envelope (Kuzmina et al., 2019). The embryonization of larval development in $H$. psittacea is probably the result of the necessity of protect the ontogenetic stages under the egg envelopes, because the development takes a long period of time in cold water of the White Sea.

Before the present investigation, two types of life cycles were known for Rhynchonelliformea: a life cycle characterized by external fertilization and development in the water column, and a life cycle characterized by the fertilization and the brooding of larvae in the mantle cavity. The plesiomorphic life cycle of recent Rhynchonelliformea probably included external fertilization, a free-swimming blastula, gastrula, and three-lobed cephalula, which swam in the water column and reversed its mantle upon settlement. This life cycle characterizes most of the recent brachiopods in the order Terebratulida (Chuang, 1996; Pennington et al., 1999; D'Hondt, Franzen, 2001; Kuzmina et al., 2019). In contrast, all brachiopods in the order Theci- 
deida (Lacaze-Duthiers, 1861; Lüter, 2007; Seidel et al., 2012), most rhynchonellids (Long, 1964; Hoverd, 1985; Lüter, 2001b), and some terebratulids (Kowalewsky, 1874; Shipley, 1883; Swedmark, 1967; Kaulfuss et al., 2013) brood the larvae in the mantle cavity. Brooding probably arose independently in these orders (e.g., see Kaulfuss et al., 2013). In most cases, brooding is known for micromorphic brachiopods and is necessary to decrease the loss of gametes and larvae and to maximize the chances of successful fertilization(Williams et al., 1997; Lüter, 2001b; Kaulfuss et al., 2013). In Rhynchonellida, brooding was found in the lophophore (Long, 1964; Hoverd, 1985) and on the mantle (Lüter, 2001b) without the formation of specialized brooding chambers. The present paper provides the first report of external fertilization and larval development within the egg envelope for a rhynchonelliform brachiopod, i.e., H. psittacea in the order Rhynchonellida. This type of development is probably transitional to the brooding of larvae in the mantle cavity, which is characteristic of other rhynchonellids.

Why is it that H. psittacea from the San Juan Channel broods its larvae in the lophophore (Long, 1964), while H. psittacea from the White Sea has external fertilization with larval development within the egg envelope (the current study)? A possible explanation is that Hemithiris from the San Juan Channel and from the White Sea represent separate species, which should be tested with molecular methods.

Acknowledgements. I am very grateful to my colleague and friend Andrei Prudkovsky (Moscow, Russia) for valuable discussions. This study was supported by fund from the Russian Foundation for Basic Research no. 19-0400449 (material collecting, laboratory investigation, and processing of the paper) and Russian Science Foundation no. 18-14-00082-P (SEM studies). The research was carried out as part of the Scientific Project of the State Order of the Government of Russian Federation to Lomonosov Moscow State University no. 121032300121-0.

\section{References}

Altenburger A., Wanninger A. 2010. Neuromuscular development in Novocrania anomala: evidence for the presence of serotonin and a spiralian-like apical organ in lecithotrophic brachiopod larvae// Evo. Dev. Vol.12. No.1. P.16-24.

Altenburger A., Wanninger A., Holmer L.E. 2013. Metamorphosis in Craniiformea revisited: Novocrania anomala shows delayed development of the ventral valve // Zoomorphology. Vol.132. No.4. P.379-387.

Conklin E.G. 1902. The embryology of a brachiopod, Terebratulina septentrionalis Couthouy // Proc. Am. Philos. Soc. Vol.41. P.41-76.

Chuang S.H. 1977. Larval development in Discinisca (inarticulate brachiopod) // Am. Zool. Vol.17. P.3953.

Chuang S.H. 1996. The embryonic, larval, and early postlarval development of the terebratellid brachiopod Calloria inconspicua (Sowerby) // J. R. Soc. New Zealand. Vol.26. No.1. P.119-137.

Emig C.C. 1997. Ecology of inarticulated brachiopods // R.L. Kaesler (ed.). Treatise on invertebrate paleontology Boulder, Colorado, and Lawrence, Kanzas: Geological Soc. America Inc. \& Univ. Kanzas. Part H. Brachiopoda. Revised. Vol.1. Introduction. P.473502.

Freeman G. 1999. Regional specification during embryogenesis in the inarticulate brachiopod Discinisca // Dev. Biol. Vol.209. P.321-339.

Freeman G. 2003. Regional specification during embryogenesis in Rhynchonelliform brachiopods // Dev. Biol. Vol.261. P.268-287.

D'Hondt J.L., Franzen A. Observations on embryological and larval stages of Macandrevia cranium (Müller, 1776) (Brachiopoda, Articulata) // Inv. Repr. Dev. Vol.40. P.153-161.

Hoverd W.A. 1985. Histological and ultrastructural observations of the lophophore and larvae of the brachiopod Notosaria nigricans (Sowerby, 1846) // J. Nat. Hist. Vol.19. P.831-850.

Hirai E., Fukushi T. 1960. The development of two species of lamp shells, Terebratalia coreanica and Coptothyris grayi // Bull. mar. biol. Stn Asamushi. Vol.10. P.77-80.

Kaulfuss A., Seidel R., Lüter C. 2013. Linking Micromorphism, Brooding, and Hermaphroditism in Brachiopods: Insights from Caribbean Argyrotheca (Brachiopoda) // J. Morphol. Vol.274. P.361-376.

Kovalevsky A.O. 1874. [Nablyudeniya nad razvitiem Brachiopoda (On the development of the Brachiopoda] // Izvestiya Obschestva Lyubiteley Estestvoznaniya, Anthropologii i Etnographii. Vol.14. P.1-40.

Kovalevsky A.O. 1883. Observations sur le developpement des brachiopods (Analysis by Oehlert and Deniker) // Arch. Zool. Exp. Gen. Sér. 2. P.57-76.

Kuzmina T.V., Malakhov V.V., Temereva E.N. 2019. Larval development of the brachiopod Coptothyris grayi (Davidson, 1852) (Terebratulida: Rhynchonel- 
liformea) and the evolution of brachiopod life cycles // Invert. Zool. Vol.16. No.1. P.27-40.

Lacaze-Duthiers F.J.H. de. 1861. Histoire naturelle des Brachiopodes vivantes de la Méditerranée. Iie Monographie. Histoire naturelle de la Thécide (Thecidium mediterraneum) // Ann. Sci. Nat. Zool. Sér.4. Vol.15. P. 259-330.

Long J.A. 1964. The embryology of three species representing three superfamilies of articulate Brachiopoda. [dissertation]. Seattle, WA: University of Washington. $185 \mathrm{p}$.

Lüter C. 2000. The origin of the coelom in Brachiopoda and its phylogenetic significance // Zoomorphology. Vol.120. P.15-28.

Lüter C. 2001a. Brachiopod larval setae - a key to the phylum's ancestral life cycle? // H. Brunton, L.R.M. Cocks, S.L. Long (eds.). Brachiopods Past and Present. Proceedings of the Millennium Brachiopod Congress, 2000. The Systematics Association. Special Volume Series 63. London: Taylor and Francis. P.46-55.

Lüter C. 2001b. Larval brooding and development of the micromorph rhynchonellid Tethyrhynchia mediterranea (Brachiopoda, Recent) // J. Mar. Biol. Assoc. UK. Vol.81. P.939-942.

Lüter C. 2007. Anatomy // R.L. Kaesler (ed.). Treatise on invertebrate paleontology. Boulder, Colorado, and Lawrence, Kanzas: Geological Soc. America Inc. \& Univ. Kanzas. Part H. Brachiopoda. Revised. Vol.6. Supplement. P.2321-2356.

Malakhov V.V. 1976. [Certain stages of embryogenesis in Cnismatocentrum sakhaliensis parvum (Brachiopo$\mathrm{da}$, Testicardines) and the problem of evolution of the way of origin of coelomic mesoderm] // Zoologicheskii Zhurnal. Vol.55. No.1. P.66-75 [in Russian, with English summary].

Malakhov V.V. 1983. [Anatomy of the Larvae of the Articulate Brachiopod Cnismatocentrum sakhaliensis parvum] // Trudy Zoologicheskii Instituta AN SSSR. Leningrad. Vol.109. P.147-55 [in Russian].

Malakhov V.V., Kuzmina T.V., Madison A.A. 2021. Classification of planktonic stages of extant brachiopods // Invert. Zool. Vol.18. No.2. P.95-104.

Nielsen C. 1991. The development of the brachiopod Crania (Neocrania) anomala (O.F. Müller) and its phylogenetic significance // Acta Zool. Vol.72. P.728.

Pennington J.T., Tamburri M.N., Barry J.P. 1999. Development, temperature tolerance, and settlement preference of embryos and larvae of the articulate brachiopod Laqueus californianus // Biol. Bull. Vol.196. P.245-256.

Percival E. 1944. A contribution to the life-history of the brachiopod Terebratella inconspicua Sowerby // Trans. R. Soc. New Zealand. Vol.74. P.1-23.

Percival E. 1960. A contribution to the life-history of the brachiopod Tegulorhynchia nigricans // Quat. J. microsc. Sci. Vol.101. P.439-457.

Prudkovsky A.A., Ekimova I.A., Neretina T.V. 2019. A case of nascent speciation: unique polymorphism of gonophores within hydrozoan Sarsia lovenii // Sci. Rep. Vol.9. No.15567.

Seidel R., Hoffmann J., Kaulfuss A., Lüter C. 2012. Comparative histology of larval brooding in Thecideoidea (Brachiopoda) // Zool. Anz. Vol.251. P.288296.

Shipley A.E. 1883. On the structure and development of Argiope // Mitt. Sta. Zool. Neapel. Vol.4. P.494-520.

Stricker S.A., Reed C.G. 1985. The Ontogeny of Shell Secretion in Terebratalia transversa (Brachiopoda, Articulata) 1. Development of the Mantle // J. Morphol. Vol.183. P.233-250.

Swedmark B. 1967. Gwynia capsula (Jeffreys), an articulate brachiopod with brood protection // Nature. Vol.213. P.1151-1152.

Williams A., Carlson S.J., Brunton C.H.C., Holmer L.E., Popov L. 1996. A supra-ordinal classification of the Brachiopoda // Philos. Trans. R. Soc. B. Vol.351. No.1344. P.1171-1193.

Williams A., Carlson S.J. 2007. Affinities of brachiopods and trends in their evolution // R.L. Kaesler (ed.). Treatise on invertebrate paleontology. Boulder, Colorado, and Lawrence, Kanzas: Geological Soc. America Inc. \& Univ. Kanzas. Part H. Brachiopoda. Revised. Vol.6. Supplement. P.2820-2877.

Williams A., Carlson S.J., Brunton C.H.C. 2000a. Subphylum Craniiformea // R.L. Kaesler (ed.). Treatise on invertebrate paleontology. Boulder, Colorado, and Lawrence, Kanzas: Geological Soc. America Inc. \& Univ. Kanzas. Part H. Brachiopoda. Revised. Vol.2: Linguliformea, Craniiformea, and Rhynchonelliformea. P.158.

Williams A., Carlson S.J., Brunton C.H.C. 2000b. Subphylum Linguliformea // R.L. Kaesler (ed.) Treatise on invertebrate paleontology. Boulder, Colorado, and Lawrence, Kanzas: Geological Soc. America Inc. \& Univ. Kanzas. Part H. Brachiopoda. Revised. Vol.2: Linguliformea, Craniiformea, and Rhynchonelliformea. P.30-157.

Williams A., Carlson S.J., Brunton C.H.C. 2000c. Subphylum Rhynchonelliformea // R.L. Kaesler (ed.). Treatise on invertebrate paleontology. Boulder, Colorado, and Lawrence, Kanzas: Geological Soc. America Inc. \& Univ. Kanzas. Part H. Brachiopoda. Revised. Vol.2: Linguliformea, Craniiformea, and Rhynchonelliformea. P.193-195.

Williams A., James M.A., Emig C.C., Mackay S., Rhodes M.C. 1997. Anatomy // Kaesler R.L. (ed.). Treatise on invertebrate paleontology. Boulder, Colorado, and Lawrence, Kanzas: Geological Soc. America Inc. \& Univ. Kanzas. Part H. Brachiopoda. Revised. Vol.1. Introduction. P.7-188.

Yatsu N. 1902. On the development of Lingula anatina // Journal of the College of Science, Imperial University, Tokyo, Japan. Vol.17. No.4. P.1-112.

Responsible editor E.N. Temereva 